\title{
Gabriel Ferrater: A Note on Science, Ideas, and Poetry
}

\author{
Joan-Josep Vallbé* (Faculty of Law, Universitat de Barcelona) \\ vallbe@ub.eduｈttp://orcid.org/0000-0001-8327-7774
}

\begin{abstract}
This paper discusses the relationship between the theory of art and the philosophy of science. In particular, it explores Catalan poet and critic Gabriel Ferrater's theory of ideas in poetry and specifically his critique of social or realist poetry. The paper shows, on the one hand, that Ferrater's theory is both antiexpressionist and anti-inductivist, and on the other, that his way of approaching both poetry and criticism can be integrated into the falsationist theoretical framework developed by philosopher of science Karl Popper to understand the process of scientific discovery.
\end{abstract}

Keywords: Gabriel Ferrater, Karl Popper, expressionist theories, induction, deduction

\section{Introduction}

In his volume devoted to Ferrater's criticism entitled La crítica de Gabriel Ferrater, Jordi Julià (2004) discusses one of the elements of Ferrater's theory of poetry: the role ideas in the poetic process. To do that, Julià cites one of Ferrater's celebrated conferences about the Catalan poet and critic Carles Riba, published posthumously in the volume La poesia de Carles Riba. Let me begin with a long citation of Ferrater's statement (Ferrater, 1979):

“Actualment circula per aquest país una mena d'escola de pensament [...] sobre les matèries del que és la poesia i del que és la literatura, que tendeix a fer-ho desembocar tot en ideologia. És el que en diuen la poesia social, la poesia realista, etc. Tendeix a fer veure que la finalitat de la literatura són les idees que manifesta. Ara bé: això és absolutament pervers i exactament el contrari del que és el cas. Les idees (quan algú és capaç de tenir-ne, com Riba n'era capaç) són el començament de la poesia, no pas el final. El final és simplement una pura imatge [...] de les idees que hi havia al començament; però les idees no poden ser mai la finalitat de la poesia. Hem de tenir una mica de sentit comú: si tenim idees $\mathrm{i}$ les expressem en un poema, les idees les hem de tenir abans de començar a escriure el poema. Aleshores, si la finalitat del poema és de comunicar les idees, el poema és inútil, perquè les idees ja les tenim abans".

\footnotetext{
* Joan-Josep Vallbé holds a PhD in Political Science from the University of Barcelona (UB), and is Associate Professor of Political Science at UB's Department of Political Science and Constitutional Law. His current research interests cover a variety of fields, including political behavior; the relationship between geography and participation and representation; the political economy of decentralization and voting; and the impact of transparency on trust.

1 "In this country there is some sort of school of thought $[\ldots]$ about what poetry is and what is literature that ends up interpreting everything in terms of ideology. It is the so-called social poetry, realist poetry, etc. It tends to defend that the goal of literature are the ideas expressed in it. Now, this is absolutely perverse and exactly the opposite of what is actually the case. Ideas (when someone is able to produce any, like Riba was) constitute the beginning of poetry, not the end of it. The
} 
I contend that the implications of this citation on the appraisement of Ferrater's theory of poetry have been underestimated. Three possible, non-exclusive interpretations of the statement cited above are the following. The first one would be that Ferrater's attack on certain uses of poetry with ideological motivation refers to a basic misunderstanding of how poetry is produced. Actually, immediately after the citation provided above, Julià clarified that this has to do with a general misunderstanding about the very process of knowledge creation: "els únics que poden creure que la finalitat de la literatura és de comunicar idees són la gent que, com deia Galileo, 'non hanno mai saputo veramente come è fatto il sappere': és a dir, la gent que no ha tingut mai idees, la gent que són uns quecs intel-lectuals i que es creen una aparença d'idees mentre van escrivint el poema" (Ferrater 1986: 509-521). ${ }^{2}$ Second, it can be understood literally, i.e., as an instance of his stand against ideologues who use poetry for inappropriate purposes, which eventually renders that kind of poetry simply trivial. Finally, Ferrater's theory of ideas in poetry has been used as an entry point to his method of literary criticism, his ideas of scientific literary criticism, and his intellectual relationship with the theories of literature.

Despite the great difficulty imposed by the fragmented nature of Ferrater's theoretical work - scattered in a few articles and numerous brief book reviews written for publishing companies during the 1960s - his aesthetic and critical theories have been thoroughly studied by critics and historians in the last decade (Oller, 2001; Julià 2004; Julià 2007). This critical work, however, has mainly dealt with the matter of Ferrater's theory on the role of ideas in poetry according to the second and third interpretations given above. For instance, Jordi Julià has brilliantly presented and discussed the quotation at the beginning of this paper in the context of Ferrater's intellectual struggle with both Marxist criticism and the New Criticism (Julià 2004; Julià 2007). However, the implications of the poet's vision of poetry as knowledge (given by the first interpretation of that quotation) and its role in his theory of poetry has so far, to my knowledge, been largely unexplored.

These notes intend to briefly elaborate on the conjecture that these interpretations can be integrated into a unified theory of poetry that can lead to scientific literary criticism. In the following sections, I show, on the one hand, that Gabriel Ferrater's theory of ideas in literature provides him with an anti-expressionist and deductive theory of poetry that significantly resembles Karl Popper's theories of art and scientific discovery. On the other hand, I contend that this theory of poetry has implications for Ferrater's notion of, and method for, criticism.

\section{Anti-expressionist theory of art}

Ferrater's opposition to the expression of ideas as the main purpose of art bears a clear notion of the poetic process. The first core concept of such a notion in his statement is that of triviality. About the communication of ideas as the main purpose of poetry, he says: "if the end of the poem is to communicate ideas, the poem becomes useless, because we already had those ideas before we wrote it". Ferrater's concept of triviality here is twodimensional. First, the fact that some poem contains ideas is trivial because a poet is someone who has ideas in the first place, not someone who needs poetry to create or express ideas. Therefore, second, poetry must not be understood as a way to express ideas, because poems are not artefacts specifically designed to express a poet's ideas. Before exploring what Ferrater understood to be the matter of poetry, let us briefly explore the argument of triviality.

Karl Popper (2005) used a similar argument to attack the theories that understood art as self-expression of the artist's personality or emotions:

end of poetry is a pure image [...] of the ideas that were produced in the beginning; yet ideas can never be the end of poetry. We should have a bit of common sense: if we have ideas and express them in a poem, we should have these ideas before we start writing the poem. Then, if the end of the poem is to communicate ideas, the poem becomes useless, because we already had those ideas before we wrote it."

2 "Those who believe that the end of literature is to communicate ideas are people that, as Galileo said, "non hanno mai saputo veramente come è fatto il sappere' [have never really known how knowledge is produced]: that is, people who have never had ideas themselves, intellectual stutterers who create an appearance of ideas while writing a poem." 
My main criticism of this theory is simple: the expressionist theory of art is empty. For everything a man or an animal can do is (among other things) an expression of an internal state, of emotions, and of a personality. This is trivially true for all kinds of human and animal languages. It holds for the way a man or a lion walks, the way a man coughs or blows his nose, the way a man or a lion may look at you, or ignore you. It holds for the ways a bird builds its nest, a spider constructs its web, and a man builds his house. In other words it is not a characteristic of art. For the same reason expressionist or emotive theories of language are trivial, uninformative, and useless. I do not of course propose to answer the what-is? question "What is art?", but I do suggest that what makes a work of art interesting or significant is something quite different from self-expression.

I find the parallelism between Popper and Ferrater remarkable: art is not specifically the product of the artist's emotional (ideological) self-expression, because emotions (ideas) are pervasive in most human activities. Should poetry constitute mainly a medium for the expression of ideas, it would be useless ("the poem becomes useless", Ferrater, 1979); it would cease to be peculiar or distinctive, because humans express ideas and emotions throughout.

Of course, this principle does not deny the emotional or ideological value of a work of art. Popper, for instance, acknowledged a couple of paragraphs after that statement the emotional impact that Bach's St Matthew Passion had on him (Popper, 2005). Ferrater himself concedes (Ferrater, 1986) that poems may present ideological content: "Of course, I hardly practice political poetry, but it is understandable that someone for whom politics is of great value in life, in his personal experience, introduces it in poetry". ${ }^{3}$ Popper's and Ferrater's objectivist theory only implies that the ideological or emotional content of a poem, if present, is not relevant for a theory of poetry, and that any such theory based upon the need to express ideas is, in Popper's words, "utterly trivial". As he put it:

to admit the emotional impact of music is not, of course, to accept musical expressionism, which is a theory about music (and a theory which has led to certain musical practices). It is, I think, a mistaken theory of the relation between human emotions on the one side and music-and art in general - on the other. ${ }^{4}$ (Popper, 2005)

This anti-expressionist principle leads to a necessary separation between the work of art and its author, and to the conclusion that what is of interest in poetry is the poem itself, not the ideas in the poet's mind. It is in this direction that we may understand Eliot's (2002) claim in Tradition and the Individual Talent (1921) that "the emotion in art is impersonal", because "it is not his personal emotions, the emotions provoked by particular events in his life, that the poet is in any way remarkable or interesting" (Eliot 2002). The poet, therefore, needs to be neither an experimenter of emotions nor an abnormally emotional person; her duty "is not to find new emotions, but to use the ordinary ones and, in working them up into poetry, to express feelings which are not in actual emotions at all" (Eliot 2002). It is only through this mechanism that Eliot's theory of the "objective correlative" can be relevant and useful for criticism: emotions and ideas are not expressed but need to be created by poets. What a poet creates is, therefore, not a reflection of her ideas or experience, but a product of what Gabriel Ferrater (1986), Joan Ferraté (1968), and Lionel Trilling (1950) called the poet's moral imagination. ${ }^{5}$

Poets must above all have imagination, then. Ferrater's focus on images and how poets masterfully present them through form is at the core of his critical efforts, as can be observed in his studies on Josep Carner (Ferrater 2001; 2004), Carles Riba (Ferrater, 1979), and J.V. Foix (Ferrater, 1987).

\footnotetext{
3 “Yo, desde luego, practico muy poco la poesía política, pero una persona para quien la política tiene importancia en su vida, en su experiencia personal, pues me parece muy bien que la traduzca en poesía."

${ }^{4}$ Just for the sake of clarity, the problem of expressionism is not only to be found in theories of art, but also seriously affects the so-called "interpretivist" approaches in the social sciences, such as critical discourse analysis (CDA). According to CDA, discursive categories (e.g., gender, race) are at the same time "constituted by social situations, institutions, and structures" (Fairclough, 1992), and the main mechanism "that enables participants in a community to make sense of and structure their particular social practices" (Lazar, 2007). Discourse, therefore, expresses and reproduces patterns of social domination. This explains, in part, the great struggles of CDA with empirical social science.

${ }^{5}$ The concept has already been thoroughly explained and discussed by Jordi Julià in his book L'art imaginatiu. Les idees estètiques de Gabriel Ferrater (2007), to which I refer for an expansion. See also Terry (2001).
} 


\section{Deductive theory of poetry}

After exploring Ferrater's anti-expressionist notion of poetry, we are ready to address his theory of poetry as knowledge, which is mainly anti-inductivist. Take, for instance, the following explanation of his own creative process (Ferrater, 1986):

My first volume [of poetry] was written through the following mental process: I thought I had to write a poem about a particular subject, which was a product of my moral, psychological observation, about people; then I waited a couple of weeks until suddenly this purely abstract, intellectual theme settled on a particular anecdote or on some observation occurred in the street. (Almost all my early poems take place in the street.) Once I found this, the poem was practically finished. ${ }^{6}$

Now compare this with Popper's explanation of the logic of scientific discovery (Popper, 2005):

Our theories, beginning with primitive myths and evolving into the theories of science, are indeed manmade, as Kant said. We do try to impose them on the world, and we can always stick to them dogmatically if we so wish, even if they are false (as are not only most religious myths, it seems, but also Newton's theory, which is the one Kant had in mind). But although at first we have to stick to our theories - without theories we cannot even begin, for we have nothing else to go by - we can, in the course of time, adopt a more critical attitude towards them. We can try to replace them by something better if we have learned, with their help, where they let us down. Thus there may arise a scientific or critical phase of thinking, which is necessarily preceded by an uncritical phase.

Kant, I felt, had been right when he said that it was impossible that knowledge was, as it were, a copy or impression of reality. He was right to believe that knowledge was genetically or psychologically a priori, but quite wrong to suppose that any knowledge could be a priori valid. Our theories are our inventions; but they may be merely ill-reasoned guesses, bold conjectures, hypotheses. Out of these we create a world: not the real world, but our own nets in which we try to catch the real world.

The parallelism between Popper and Ferrater I find, again, compelling. Ferrater's vision can be reformulated in Popperian terms: the poet (scientist) elaborates an idea (hypothesis, conjecture) and transforms it into an image (an attempt of refutation) to be matched with the world. This process has two distinct relevant stages. First, the process begins as a human-made conjecture or image, not in the world itself. As Ferrater says, this image (Popper's refutation "object") is an image of the idea (hypothesis) that the poet (scientist) had in the beginning. Second, the purpose of the process is to impose order on the world, through what Joan Ferraté called a formalization of experience (Ferrater, 1968), which he later on renamed formalization of conscience (Ferrater, 1991).

Obviously, science and poetry are different endeavours, but both are creative in nature, as Eduard Bonet's book on Ferrater's intertwined interests in poetry, mathematics and linguistics (Bonet, 2009) shows magnificently. In science, the attempt of refutation has to be carried out consistently, in coherence with the hypothesis that is to be tested: data should fit the purpose. The poet, according to Ferrater, does not wait for events from reality to impress on him some idea to be transformed into a poem, but creates an object triggered by an initial, abstract idea (the poem, which is an image of that idea) that in turn must be consistent with the world. Unless ideas are genuine and occur at the beginning of the process, the poet's enterprise is trivial, as is ill-fated the scientist who creates theories that can't be tested: "a method that can explain everything that might happen explains nothing," which is Popper's definition of pseudo-science (Popper, 1957).

Ferrater's theory about the role of ideas (or ideologies) in poetry and art in general is, therefore, anti-inductivist, as is Popper's theory of the logic of scientific discovery. It is an idea, a conjecture about the world which triggers the observation of the world (the creation of the poem), not the other way around. In a more systematic

\footnotetext{
6 "Mi primer libro está escrito por el procedimiento mental siguiente: yo pensaba que había que escribir un poema sobre tal tema, producto de la observación moral, psicológica, sobre la gente; y entonces esperaba dos o tres semanas a que de pronto este tema puramente abstracto, intelectual, se concretara mediante una anécdota o mediante la observación de una cosa vista por la calle. (Casi todos mis primeros poemas ocurren en la calle.) Y al encontrar eso, el poema ya estaba prácticamente hecho."
} 
way, Joan Ferraté defined the poetic symbol (the image) as "The poetization that, instead of starting from reality to discover its spiritual meaning in it, it parts from the spiritual meaning itself and tries to find an adequate symbolic correspondence in reality" (Ferrater, 1968). The first process identified by Ferraté ("starting from reality to discover its spiritual meaning in it") is a form of induction; the second one is a form of deduction.

The scientist, Popper says, dominates the world with theories (Popper, 2002), and it is therefore theory that makes us observe the world in such a way that an attempt at refutation is possible at all. Scientific knowledge is not logically possible through induction (Popper, 2002), because theory cannot be generalized from facts. In a similar way, the poet must have an idea that allows her to produce the poetic image that intends to impose order on the world, what Popper calls "a cosmos imposed upon chaos" (Popper 2005). This is the actual poetic process explained by Ferrater (1986) above: "I waited a couple of weeks until suddenly this purely abstract, intellectual theme settled on a particular anecdote or on some observation occurred in the street." According to Ferrater, moreover, these abstract ideas should be genuine ("when someone is able to produce any, like Riba was" Ferrater 1979), not dominated by ideologies, although this is a statement about the quality of a poet, not an essential component of his theory of poetry.

As someone who attempts to put order upon the world, in sum, the poet is an active agent, not someone who just passively channels emotions, ideologies, or facts. For poetry to be successfully achieved, the poet must have genuine ideas about the world that trigger the creation of a poetic object that, once produced, is thrown into the world. The poet's technique, as Ferrater said, "és una tècnica de disciplina intel-lectual i moral" (Ferrater, 2001), ${ }^{8}$ not a mere technique of expression of actual experiences or ideas.

The poem, like a hypothesis, is an attempt to impose order upon the world, which brings us, finally, to the possibility of scientific literary criticism.

\section{Criticism}

Ferrater's stand on criticism revealed an intellectual shield against Marxist literary criticism, which during his lifetime owned a good share of academic life. In particular, although Ferrater acknowledged certain value in the criticism carried out by some Marxist critics such as Lukács, his serious commitment to the tradition of Riba, Spitzer, Trilling and Wilson (Julià 2004), along with his intellectual independence, granted him a valid strategy to avoid the great limitations of extremely formalist proposals such as structuralism and the New Criticism, on the one hand, and the sociological excesses of most Marxist literary criticism, on the other.

According to what has been presented above, the critic deals with an ordered image, with the poet's proposal of formalized experience (Ferraté, 1968) or conscience (Ferraté, 1991). The task of the critic (and the reader's), then, is to uncover the path from the ordered entity (the poem) to the "initial disorder"-that triggered the ordered image, a particular instance of the poet's moral imagination. However, given the nature of the poem (as a proposal of formalized experience) and its separation from the poet's actual ideas or emotions, this disentanglement must be carried out within the work itself, through the understanding of its data and of the specific formal structure linking the data components. In his volume on Ferrater as critic (Julià 2004), Jordi Julià traces back this notion of the task of the critic to Carles Riba and Leo Spitzer. Riba summarized this task thus: "To trace (to the very core of the work, if necessary) the principles of its creation, and then re-create them, wholly or in detail, keeping those principles explicit" (cited by Julià, 2004). ${ }^{9}$ Joan Ferraté gives it a more systematic form (Ferraté, 1968):

\footnotetext{
7 "la poetización que en vez de partir de la realidad para descubrir en ella su sentido espiritual, parte del sentido espiritual mismo y trata de hallarle adecuada correspondencia simbólica en la realidad".

8 "és una tècnica de disciplina intel·lectual i moral".

9 "perseguir, fins al centre de l'obra si cal, els principis de la seva creació i refer-la llavors, en conjunt o en detall, mantenint explícits aquells principis."
} 
The work of art [...] is defined as a proposal to operate from particular material data. Yet, the operation itself has a mainly formal character. The work of art, in effect, is realized only through the reception of data in the intimacy of the reader, the art contemplator, the music spectator. In addition, this reception is carried out through movements of the spirit that, driven and regulated by the material elements of the work, are purely formal themselves. In other words, what is presented in the work of art as material data is translated into pure spiritual activity in the recipient's intimacy. ${ }^{10}$

According to this theory of reception, in poetry (in art) the moral idea that becomes formalized experience with the poem is not readily accessible to the recipient. The critic (the reader) deals only with the object itself: the ordered image. The reader's duty is then to understand which moral idea is a better match for the given image.

This, certainly, is not how science works, because each attempt at hypothesis testing must contain a clear explanation of the whole path going from the initial idea (the hypothesis and the theory from which it is derived) to a complete interpretation of the results (the contrast of the scientist's "ordered proposal" with the world) to determine whether they match the initial idea. If poetry worked like science, poems would always come accompanied with the following:

1. The enunciation of the moral idea of which the poem is an image.

2. A comment about all the ways in which the poem is a product of the initial moral idea.

Of course, because this is not the case, poetry and art can be seen as a game (of the disentanglement of the image), while science must not. The formal structure of the poem is what the reader can use to disentangle what Wallace Stevens (1997) defined as "the life that is lived in the scene that it composes", and Joan Ferrate called the "inner form" (Ferrate 1968) of art. This is also why Ferrater understood that the moral idea that triggers the conception of a poem must be an interesting one, to be worth the effort.

\section{Conclusions}

We can now revisit the role of ideology in poetry, and reformulate Ferrater's critique in the following terms: social or political art is poor ${ }^{11}$ because the mechanism linking the poet and the artistic object she creates (the poem) is not used to create an image of her moral imagination, but as a channel to communicate a system of ideas (ideology) which are either not her own or produced during the process of creation. In both cases, Ferrater's theoretic principle is violated, but while in the first case the problem affects the quality of the poem, in the second one it also collides with this whole notion of the poetic process.

I think he is referring to both problems in the following fragment of one of his most celebrated poems ("Poema inacabat" [“Unfinished poem”]) (Ferrater, 1979):

I don't go around fairs with mules I to carry certainties: |

should I someday reach any, I'd lose I the freedom to give them up I and it's freedom I want to be good at. ${ }^{12}$

Certainties - systems of belief that explain everything, which is what ideologies provide - are uninteresting for poetry, according to Ferrater. This is why Ferrater considered social poetry a trivial activity. For the same reason, Popper thought the abuse of ideology in social sciences (i.e., pseudo-science based on non-testable

\footnotetext{
10 "La obra de arte [...] se define como una propuesta de operar a partir de unos datos materiales determinados. Pero la operación misma tiene un carácter eminentemente formal. La obra de arte, en efecto, se actualiza sólo con la recepción de los datos en la intimidad del lector, contemplador, auditor. Y dicha recepción se realiza en movimientos del ánimo que, impulsados y regulados por los elementos materiales de la obra, son en sí mismos puramente formales. Esto es, lo que en la obra se ofrece como dato material, en la intimidad receptora se traduce en pura actividad espiritual."

${ }^{11}$ Understanding poverty as sterility, which is how Popper uses the word in The Poverty of Historicism (Popper 1957).

12 "Jo no corro fires amb mules per carregar de certituds: si un dia en tinc, hauré perdut llibertat de renunciar-hi i és a ser lliure que em vull hàbil. (Si vols marxants de certituds, et diré noms: en sé més d'un.)."
} 
statements) prevents knowledge accumulation. It is in this way, in sum, that Ferrater understood poetic objects as images of the poet's moral imagination. And this is the only way he could understand tradition.

Ferrater's inversion of Eugeni d'Ors famous statement about tradition can be understood in these terms (Ferrater 1979):

What Eugeni d'Ors actually means by saying that what is not tradition constitutes plagiarism is that a person with no culture, with no tradition, who writes spontaneously and completely unaware of what has been written before, will probably repeat something that has already been done while pretending it to be a novelty. Well, when I state that 'what is not plagiarism constitutes tradition' I mean, inversely, that every conscious writer who really intends to modify the state, the situation, the dynamics of literature must critically analyze everything that has been written before, because he depends on it in order to confront it. ${ }^{13}$

The poet, then, not only intends to put order upon the world, but also actively inquires tradition and creates objects that build critically on it. Sometimes these objects do successfully so, sometimes they do not, which echoes trial and error. As Popper says (1962), "without waiting, passively, for repetitions to impress or impose regularities upon us, we actively try to impose regularities upon the world. [...] These may have to be discarded later, should observation show that they are wrong", thus constituting a process of "conjectures and refutations". D'Ors' notion of tradition is passive, inductive, while Ferrater's is active, deductive.

In a paper published in 1953, Gabriel Ferrater acknowledged that "there is no critical knowledge; criticism is not a science" (1981). Within Ferrater's (and Ferraté's) anti-expressionist and deductionist theoretical framework, accumulation of knowledge is possible and literary criticism can get rid of impressionism.

\section{References}

Bonet, E.: Gabriel Ferrater $i$ Robert Musil: Entre les lletres $i$ les ciències, Barcelona: Residència d'Investigadors CSIC-Generalitat de Catalunya, Barcelona, 2009.

Eliot, T.S.: Hamlet and his problems. In: The Waste Land and other Writings, New York: Modern Library, 2002, pp. 137-143.

Eliot, T.S.: Tradition and the individual talent. In: The Waste Land and Other Writings, New York: Modern Library, 2002, pp. 99-108.

Fairclough, N.: Discourse and social change, Cambridge: Polity Press, 1992.

Ferraté, J.: Aspectos de la obra de arte. In: Dinámica de la poesía. Ensayos de explicación, 1952-1966, Barcelona: Seix Barral, 1968, pp. 11-19.

Ferraté, J.: Ficción y realidad en la poesía de Góngora. In: Dinámica de la poesía. Ensayos de explicación, 1952-1966, Barcelona: Seix Barral, 1968, pp. 297-334.

\footnotetext{
13 “Eugeni d’Ors, l'únic que vol dir amb això que el que no és tradició és plagi, és que la persona sense cultura, sense tradició, i que escriu espontàniament i sense saber res del que s'ha escrit abans d'ell, probablement el que farà és repetir alguna cosa que ja ha fet algú abans, creient-se que és una novetat. Bé, jo vull dir quan dic "tot allò que no és plagi és tradició", que, inversament, tot escriptor conscient i que vol realment modificar l'estat, la situació, la dinàmica d'una literatura, per fer això ha d'analitzar críticament, justament, tot el que s'ha fet abans d'ell, i que, per tant, en depèn molt en l'ordre d'oposar-s'hi."
} 
Ferraté, J.: Poesía y símbolo. In: Dinámica de la poesía. Ensayos de explicación, 1952-1966, Barcelona: Seix Barral, 1968, pp. 83-118.

Ferraté, J.: La formalització de la consciència. In: Apunts en net, Barcelona: Quaderns Crema, 1991, pp. 39-45.

Ferrater, G.: Gabriel Ferrater o las mujeres, por Federico Campbell. In: Papers, cartes, paraules, Barcelona: Quaderns Crema, 1986,pp. 509-521.

Ferrater, G.: La poesia de Carles Riba, Barcelona: Edicions 62, 1979.

Ferrater, G.: Les dones i els dies. Barcelona: Edicions 62, 1979.

Ferrater, G.: Sobre la posibilidad de una crítica de arte. In: Sobre pintura, Barcelona: Seix Barral, 1981, pp. 95113.

Ferrater, G.: Papers, cartes, paraules, Barcelona: Quaderns Crema, 1986.

Ferrater, G.: Foix i el seu temps, Barcelona: Quaderns Crema, 1987.

Ferrater, G.: Pròleg. In: Carner, J., Nabí, Barcelona: Edicions 62/ Empúries, 1998, pp. 7-27.

Ferrater, G.: Dues conferències inèdites sobre poesia catalana (c. 1972). In: Oller, D., Subirana, J. (eds.), Gabriel Ferrater, 'in memoriam', Barcelona: Proa, 2001, pp. 17-69.

Julià, J.: La crítica de Gabriel Ferrater. Estudis d'una trajectòria intel·lectual. Lleida: Pagès editors, 2004.

Julià, J.: L'art imaginatiu. Les estètiques de Gabriel Ferrater. Barcelona: Institut d'Estudis Catalans, 2007.

Lazar, M.M.: Feminist critical discourse analysis: Articulating afeminist discourse praxis. Critical Discourse Studies 4(2) (2007): 141-164.

Oller, D., Subirana, J. (ed.): Gabriel Ferrater, ‘in memoriam’, Barcelona: Proa, 2001.

Popper, K.R.: The Poverty of Historicism, Boston: The Beacon Press, 1957.

Popper, K.R.: Conjectures and Refutations: The Growth of Scientific Knowledge, New York / London: Basic Books, 1962.

Popper, K.R.: The Logic of Scientific Discovery. London / New York: Routledge, 2002.

Popper, K.R.: Unended Quest. An Intellectual Autobiography. London / New York, Routledge, 2005.

Stevens, W.: The Necessary Angel. Essays on reality and the imagination. In: Collected Poetry and Prose, New York: The Library of America, 1997, pp. 637-751.

Terry, A.: Gabriel Ferrater: la moral i l'experiència. In: Oller, D., Subirana, J. (ed.): Gabriel Ferrater, 'in memoriam', Barcelona: Proa, 2001, pp. 101-125.

Trilling, L.: Huckleberry Finn. In: The Liberal Imagination. Essays on Literature and Society, New York: The Viking Press, 1950, pp. 104-117 